manufacture of gas and coke from coal, another one million tons were obtained. The quantity obtained from home-produced natural petroleum was only about two million tons. Natural petroleum gave most of the lubricating oil used, but hydrogenation processes provided almost the whole of the highgrade aviation spirit. The synthetic processes were much more costly than natural petroleum, but with Germany's policy of self-sufficiency cost was not of first importance. It has been estimated that with present-day prices of labour, coal and other materials, the cost of obtaining oil from coal in Great Britain by the processes as developed and operated in Germany would be at least two shillings a gallon, as compared with only about sixpence for imported petroleum, excluding import duties. Research should be continued, however, as there are prospects of improving the methods of obtaining oil from coal, and in certain parts of the British Commonwealth there are cheaper supplies of coal than in Great Britain, as well as reserves of brown coal and lignite. Dr. Parker stated that bombing attacks between May and September 1944 caused a reduction in German production of synthetic oil from a rate of nearly four million tons a year to only about 300,000 tons. During the following months, with a reduction in bombing and determined efforts in Germany to repair damage, production again rose to a rate of one million tons a year in November 1944, after which it again fell to 150,000 tons a year at the end of February 1945. It is certain that this system. atic destruction of German oil plants was one of the main factors in hastening the defeat of Germany.

\section{Proposed International Exhibition in 1951}

THE proposal that an International Exhibition should be held in London in 1951, with other matters relating to exhibitions, was referred by the Secretary for Overseas Trade to a representative Committee (the Ramsden Committee), which, in December 1945, recommended that an international exhibition should be held in London in 1951 or as soon as possible afterwards, and that it should be sited in Central London. The Government accepted the suggestion, but there have been difficulties in finding a site, accommodating visitors, etc. The Royal Society of Arts, which as the Society of Arts took the initiative in promoting the International Exhibition held in $\mathrm{Hyde}$ Park in 1851, has joined in advocating the holding of another and far greater Exhibition in 1951 to mark the centenary. The Society has accordingly called a conferenee for February 6, to give fuller consideration to this question and to discuss in particular: (1) whether an International Exhibition on a large scale should be held in London in the near future; (2) if so, whether Hyde Park should be the site; (3) whother every effort should be made to hold it in 1951, the centenary year of the first International Exhibition. Should the conference approve the general proposal, a formal approach would then be made to the London local authorities and to the Government.

\section{Journal of Research of the National Bureau of Standards}

WITH the July issue, which began the thirty-seventh semi-annual volume, the Journal of Research of the National Bureau of Standards, a monthly periodical published by the U.S. Department of Commerce and devoted to pure and applied science, appeared in a new typographical style and size. A larger size of page now brings the Journal into line with many other American scientific and technical magazines, such as the publications of the American Physical Society, and with that recently adopted for the Bureaa's Technical News Bulletin. Other improvements in the general format are a light blue cover, a separate 'contents' page, double reading columns, two-point spaces between the lines of text and tabular matter, and modern type for display heads. These changes make the printed page much easier to read. As in former issues, the individual articles are still printed as separate units, and reprints are made available for purchase as 'Research Papers' from the Superintendent of Documents, U.S. Government Printing Office, Washington 25, D.C., shortly after their appearance in the monthly issue of the Journal. In this respect it may be of interest to readers to know that H.M. Stationery Office has recently announced that arrangements have been made for that Office to act as agents for U.S. Government publications, and that orders should be sent to the London Sales Office, York House, Kingsway, W.C.2.

The Research Papers, Nos. 1723-29 inclusive, which appear in the July issue, deal with radio-proximity. fuse design for bombs, rockets and mortars which were mainly developed during the Second World War ; laboratory distilling columns for the analysis and purification of hydrocarbons; nickel plating on steel by chemical reduction; the temperature coefficients of proving rings used in the calibration of test machines applying forces to engineering materials and structures; the mutarotation and ring structure of mannuronic lactone; the heats of formation and combustion of certain $\mathrm{CH}_{2}$ groups; and a description and analysis of the spectrum of uranium between 2900 and $11000 \mathrm{~A}$.

\section{Intrinsic Safety of Electrical Apparatus}

THE: use of electrical appliances in coal mines needs to be safeguarded against the risk that they may be the means of igniting firedamp (or coal dust) and thus starting an explosion. Two methods are commonly employed. One is to provide a suitable enclosure from which flame cannot be ejected. The other method is to make the apparatus and related electrical circuits 'intrinsically safe', which means that any sparking which may occur when the circuit is broken at any point is incapable of causing ignition. One aspect of the latter method is discussed in a report, Paper No. 104, published recently by the Safety in Mines Research Board. It gives the relationship which has been found between the inductance in a circuit when the circuit is rapidly broken between a pointed platinum electrode and a wire and the minimum current capable of igniting firedamp. The effects of two methods of increasing the minimum igniting current have been measured. These are the introduction into the circuit of a shunting resistance or condenser. They can be of considerable value when the inductance is high and the current correspondingly low, as in apparatus such as bells, telephones, signalling and shot-firing systems, but become almost valueless when the working current exceeds about one ampere, or in the case of condenser shunts when a slow break of the circuit can occur. The results reported in this paper will be used at the Safety in Mines Testing Station in the examination of mining electrical apparatus submitted by the makers for approval. 